\title{
Phytoprotection
}

\section{Influence of crop rotation and flutolanil on the diversity of fungi on peanut shells}

\author{
R.E. Baird, T.B. Brenneman, D.K. Bell, D.R. Sumner, N.A. Minton, B.G. Mullinix \\ et A.B. Peery
}

Volume 76, numéro 3, 1995

URI : https://id.erudit.org/iderudit/706089ar

DOI : https://doi.org/10.7202/706089ar

\section{Aller au sommaire du numéro}

\section{Éditeur(s)}

Société de protection des plantes du Québec (SPPQ)l

ISSN

0031-9511 (imprimé)

1710-1603 (numérique)

Découvrir la revue

Citer cet article

Baird, R., Brenneman, T., Bell, D., Sumner, D., Minton, N., Mullinix, B. \& Peery, A. (1995). Influence of crop rotation and flutolanil on the diversity of fungi on peanut shells. Phytoprotection, 76(3), 101-113. https://doi.org/10.7202/706089ar

\section{Résumé de l'article}

Les agents pathogènes du sol qui affectent les arachides (Arachis hypogaea) survivent ou hivernent souvent sur les écales d'arachides laissées sur ou dans le sol. Les effets de diverses rotations de cultures sur la flore fongique des écales d'arachides ont été comparés par trois tests en champ menés en 1992 et en 1993. Dans deux des tests, les parcelles d'arachides cultivées de façon continue ont été traitées ou non traitées avec le fongicide flutolanil. Les pratiques de rotation ont varié avec la localisation, et les cultures en rotation avec les arachides étaient le coton (Gossypium hirsutum), le seigle (Secale céréale), l'herbe de Bahia (Paspalum notatum), et le maïs (Zea mays). Au total, 31 genres de champignon ont été isolés des écales. Plus des deux tiers des isolats étaient des Deutéromycètes, suivis en fréquence par les Basidiomycètes, les Ascomycètes et les Phycomycètes. Les pratiques de rotation ont affecté l'incidence de plusieurs champignons pathogènes (par exemple, les Fusarium spp. et le Lasiodiplodia theobromae) sur les écales d'arachides, mais les résultats n'ont pas été cohérents entre les tests et les années. L'herbe de Bahia ou le maïs cultivés en rotation avec les arachides ont réduit la fréquence du Rhizoctonia solani AG-4 dans les écales. Le Rhizoctonia solani AG-2-2 et le Macrophomina phaseolina ont été isolés à des niveaux plus élevés dans la rotation herbe de Bahia-arachide. Quand les arachides étaient cultivées en rotation avec le coton avec ou sans une culture de couverture de seigle, les parcelles recouvertes de seigle avaient des taux d'isolement moindres pour les champignons totaux en 1992 que les parcelles sans seigle, mais aucune différence n'a été observée en 1993. De plus, plusieurs espèces de Fusarium ont été isolées plus fréquemment des écales provenant de parcelles en rotation avec le seigle. Le flutolanil a diminué significativement les taux d'isolement de plusieurs champignons, incluant le $R$. solani AG-4, dans un des essais en 1992. L'ensemble des champignons isolés (en combinant tous les isolats de champignon) sur les parcelles traitées au flutolanil étaient plus élevés en 1993, mais pas en 1992 sur un des sites. Les taux d'isolement pour les différents genres et espèces de champignon différaient sur les deux milieux utilisés (agar à l'extrait de malt et agar au sel de malt). En particulier, l'AIternaria alternata et des espèces de Fusarium ont été isolés plus fréquemment sur l'agar au sel de malt, tandis que $L$ theobromae, $R$. solani AG-4 et Trichoderma spp. Étaient plus souvent rencontrés sur l'agar à l'extrait de malt.
Ce document est protégé par la loi sur le droit d'auteur. L’utilisation des services d’Érudit (y compris la reproduction) est assujettie à sa politique d'utilisation que vous pouvez consulter en ligne.

https://apropos.erudit.org/fr/usagers/politique-dutilisation/ 


\title{
Influence of crop rotation and flutolanil on the diversity of fungi on peanut shells
}

\author{
Richard E. Baird', Timothy B. Brenneman², Durham K. Bell², \\ Donald R. Sumner ${ }^{2}$, Norman A. Minton ${ }^{3}$, Benjamin G. Mullinix ${ }^{4}$, \\ and Anne B. Peery ${ }^{5}$
}

Received 1994-12-07; accepted 1996-03-18

Soilborne pathogens of peanut (Arachis hypogaea) often survive or overwinter on peanut shells left on or in the soil. The effects of different crop rotations on the peanut shell mycobiota were compared in three field trials in 1992 and repeated in 1993. In two of the trials, plots grown continuously to peanut were either treated with the fungicide flutolanil or left untreated. Rotation practices varied with location and the crops in rotation with peanut were cotton (Gossypium hirsutum), rye (Secale cereale), bahiagrass (Paspalum notatum), and corn (Zea mays). In total, 31 different genera of fungi were isolated from shells. Over two-thirds of the isolates were Deuteromycotina, followed in frequency by Basidiomycetes, Ascomycetes, and Phycomycetes. The rotation practices affected the incidence of several pathogenic fungi (e.g., Fusarium spp., and Lasiodiplodia theobromae) in the peanut shells, but the results were not consistent across trials or years. Bahiagrass or corn grown in rotation with peanut reduced the frequency of Rhizoctonia solaniAG-4 in shells. Rhizoctonia solani AG-2-2 and Macrophomina phaseolina were isolated at a greater level in the bahiagrass-peanut rotation. Where peanut was rotated with cotton with or without a winter cover crop of rye, plots containing rye had lower isolation rates for total fungi in 1992 than those without rye, but there was no difference in 1993. Also, several species of Fusarium were isolated more frequently from shells from plots rotated with rye. Flutolanil significantly lowered isolation rates of several fungi, including $R$. solani AG-4, in one trial in 1992. Total fungi isolated (all fungal isolates combined) in the flutolanil-treated plots were greater in 1993, but not in 1992 at one site. Isolation rates for the different genera and species of fungi differed on the two media utilized (malt-extract agar and malt-salt agar). In particular, Alternaria alternata and species of Fusarium were isolated more frequently on malt-salt agar, whereas $L$. theobromae, $R$. solani AG-4 and Trichoderma spp. were more common on maltextract agar.

1. Plant Pathology Department, University of Georgia, Rural Development Center, P.O. Box 1209, Tifton, Georgia 31793 USA

2. Department of Plant Pathology, University of Georgia, Coastal Plain Experiment Station, Tifton, Georgia 31793 USA

3. USDA-ARS, Coastal Plain Experiment Station, Tifton, Georgia 31793 USA

4. Statistical and Computer Services, Coastal Plain Experiment Station, Tifton, Georgia 31793 USA

5. Botany and Plant Pathology Department, Southwest Purdue Agricultural Program, Vincennes, Indiana 47591 USA 


\section{Baird, R.E., T.B. Brenneman, D.K. Bell, D.R. Sumner, N.A. Minton, B.G. Mullinix et A.B. Peery. 1995. Effet des rotations de cultures et du flutolanil sur la diversité fongique des écales d'arachides. PHYTOPROTECTION 76 : 101-113.}

Les agents pathogènes du sol qui affectent les arachides (Arachis hypogaea) survivent ou hivernent souvent sur les écales d'arachides laissées sur ou dans le sol. Les effets de diverses rotations de cultures sur la flore fongique des écales d'arachides ont été comparés par trois tests en champ menés en 1992 et en 1993. Dans deux des tests, les parcelles d'arachides cultivées de façon continue ont été traitées ou non traitées avec le fongicide flutolanil. Les pratiques de rotation ont varié avec la localisation, et les cultures en rotation avec les arachides étaient le coton (Gossypium hirsutum), le seigle (Secale cereale), I'herbe de Bahia (Paspalum notatum), et le maïs (Zea mays). Au total, 31 genres de champignon ont été isolés des écales. Plus des deux tiers des isolats étaient des Deutéromycètes, suivis en fréquence par les Basidiomycètes, les Ascomycètes et les Phycomycètes. Les pratiques de rotation ont affecté l'incidence de plusieurs champignons pathogènes (par exemple, les Fusarium spp. et le Lasiodiplodia theobromae) sur les écales d'arachides, mais les résultats n'ont pas été cohérents entre les tests et les années. L'herbe de Bahia ou le maïs cultivés en rotation avec les arachides ont réduit la fréquence du Rhizoctonia solani AG-4 dans les écales. Le Rhizoctonia solani AG-2-2. et le Macrophomina phaseolina ont été isolés à des niveaux plus élevés dans la rotation herbe de Bahia-arachide. Quand les arachides étaient cultivées en rotation avec le coton avec ou sans une culture de couverture de seigle, les parcelles recouvertes de seigle avaient des taux d'isolement moindres pour les champignons totaux en 1992 que les parcelles sans seigle, mais aucune différence n'a été observée en 1993. De plus, plusieurs espèces de Fusarium ont été isolées plus fréquemment des écales provenant de parcelles en rotation avec le seigle. Le flutolanil a diminué significativement les taux d'isolement de plusieurs champignons, incluant le $R$. solani AG-4, dans un des essais en 1992. L'ensemble des champignons isolés (en combinant tous les isolats de champignon) sur les parcelles traitées au flutolanil étaient plus élevés en 1993, mais pas en 1992 sur un des sites. Les taux d'isolement pour les différents genres et espèces de champignon différaient sur les deux milieux utilisés (agar à l'extrait de malt et agar au sel de malt). En particulier, l'Alternaria alternata et des espèces de Fusarium ont été isolés plus fréquemment sur l'agar au sel de malt, tandis que $L$. theobromae, $R$. solani AG-4 et Trichoderma spp. étaient plus souvent rencontrés sur l'agar à l'extrait de malt.

\section{INTRODUCTION}

Peanut (Arachis hypogaea L.) shells are a food base for many soilborne pathogens and have been used as indicators to measure the mycobiota levels in soil (Hanlin 1973; Jackson 1965). Specifically, Rhizoctonia spp. grow saprophytically in the peanut shells left on and in the soil after harvest (Baird et al. 1991, 1993a; Bell and Sumner 1987), but chemical treatments and management practices can influence their concentration and diversi- ty. Recent studies have shown that the soilborne pathogen Rhizoctonia solani Kühn AG-4 can survive in shells at least $2 \mathrm{yr}$ after harvesting (Baird et al. 1993a), but the survival rate decreases after the first year. The use of non-hosts in rotation with peanut may further lirnit the survival of $R$. solani AG-4.

Fungicides can influence the composition of soilborne fungi on peanut pods (Jackson 1967a,b). Shells from propiconazole [1-[[2-(2,4-dichlorophenyl)-4-propyl1,3-dioxolan-2-yl]methyl]-1H-1,2,4-tri- 
azole]-treated plots had increased isolation frequencies of Fusarium spp., Curvularia lunata (Walker) Boedijn, and Phoma spp. (Baird et al. 1991). The systemic fungicide flutolanil [3'-isopropoxy-2(trifluoromethyl)benzanilide] decreased incidence of $R$. solaniAG-4 and Trichoderma spp. from shells and increased the incidence of Fusarium solani (Martius) Appel and Wollen., and Fusarium oxysporum Schl. (Baird et al. 1993c). In a more recent investigation, however, flutolanil did not lower incidence of Rhizoctonia spp. (Baird et al. 1993b).

Disease incidence in numerous crops has been reported to decrease when debris from crops such as wheat (Triticum aestivum L.) and rye (Secale cereale L.) were left on the soil surface (Sumner et al. 1986). Pathogenic fungi such as $R$. solani AG-4, Sclerotium rolfsii Sacc., and Pythium spp., may be in direct competition with saprophytic fungi or bacteria that survive and grow on the debris. These saprophytes may be antagonistic or parasitic to the pathogens, and thereby serve as natural biological control agents (Baird et al. 1993d). Comprehensive studies to evaluate the influence of currently used rotational crops such as bahiagrass (Paspalum notatum Flügge), cotton (Gossypium hirsutum L.) or corn (Zea mays L.) on the peanut shell mycobiota have not been conducted to date.

The primary objectives of this investigation were to determine the effect of specific rotations and cover-cropping practices on the frequency of soilborne pathogens from peanut shells remaining in the soil after harvest, and to re-examine the effect of flutolanil on these fungi under different management practices.

\section{MATERIALS AND METHODS}

On 27 April 1992 and 14 May 1993, seed of peanut cv. Florunner was sown at the Georgia Coastal Plain Experiment Station, Tifton, Georgia (lat. $31^{\circ} 30^{\prime}$ N long. 83 $30^{\prime} \mathrm{W}$ ). The planting density was $123 \mathrm{~kg} \mathrm{ha}^{-1}$ of seed at the Gibbs Farm (two trials), and $117 \mathrm{~kg} \mathrm{ha}^{-1}$ at the Blackshank Farm (one trial). The fields chosen for sampling had been the site of preexisting studies in which different rotations were compared.

\section{Gibbs Farm}

The crop rotation study (GF1) was established on Tifton loamy sand (fine-loamy, thermic Plinthic Kandiudults; pH 6.3, 1992 and $\mathrm{pH} 6.1,1993$ ) and the second trial (GF2) on Clarendon loamy sand (fineloamy sand, $\mathrm{pH}$ 6.7, 1992 and $\mathrm{pH}$ 6.3, 1993). Both trials received $58 \mathrm{~cm}$ of water from May to September from rainfall and overhead sprinkler irrigation in 1992, and $41 \mathrm{~cm}$ in 1993.

The GF1 study was established in 1988 with plots of either continuous peanut or a cotton-peanut rotation with or without a winter cover of rye (cv. Wrens Abruzzi). Rye seed was planted at a rate of $114 \mathrm{~kg} \mathrm{ha}^{-1}$ on 10 December 1991, 8 December 1992, and 8 December 1993. The trial used a split-plot design with four replicates per treatment. Whole plots were the primary rotation crops (i.e. peanut and cotton) and subplots were rye cover versus no cover crop. Each subplot consisted of a single bed $(1.8 \mathrm{~m} \times 7.6 \mathrm{~m})$ with two rows as border beds on either side of a plot. Rye plots were mowed on 25 March 1992 and 11 March 1993, and all plots were moldboard plowed on 8 and 15 April for 1992 and 1993, respectively. Standard cultural practices were followed for fertilization, weed, and insect control for peanut (Johnson et al. 1987) and cotton (Baird et al. 1993d).

The GF2 rotation trial used a split-plot design with four replicates per treatment. Whole plots consisted of crop rotations, and subplots were treated or not treated with flutolanil. Each subplot consisted of a single bed $(1.8 \mathrm{~m} \times 7.6 \mathrm{~m})$ with two rows as border beds on either side of a plot. Crop rotation treatments included: 1) bahiagrass-peanut; 2) cotton-peanut; and 3) continuous peanut. Treatments for the second year were : 1) bahiagrassbahiagrass-peanut; 2) corn-corn-peanut; 3) cotton-cotton-peanut; and 4) continuous peanut. Flutolanil was applied at a rate of $0.84 \mathrm{~kg}$ a.i. ha- ${ }^{-1}$ at 60 and $90 \mathrm{~d}$ after seeding on 13 July and 10 August 1992, and 15 July and 20 August 1993. The fungicide was broadcast using a $\mathrm{CO}_{2}$ beltpack sprayer with D2-23 nozzles delivering $18.9 \mathrm{~L} \mathrm{ha}^{-1}$ of water at $136 \mathrm{kPa}$. Ba- 
hiagrass plots were burned on 12 March 1992, and 22 March 1993, and moldboard plowed on 3 April 1992 and 6 April 1993. Peanut plants in plots at both trials were inverted on 21 September 1992 and 1 October 1993 and harvested by combine after drying in the field. Detached peanut pods were collected from previously harvested plots on 14 October in 1992 and 1993.

\section{Blackshank Farm}

The field trial BF1 was initiated in 1990 to evaluate the effects of multiple year crop rotations for control of peanut soilborne pathogens. The site consisted of a Tifton loamy sand, $\mathrm{pH} \mathrm{6.3,} 1992$ and $\mathrm{pH}$ 6.3, 1993. The plots received $57.6 \mathrm{~cm}$ of water in 1992 and $52.5 \mathrm{~cm}$ in 1993 from combined irrigation plus rainfall from May to September. The plots $(5.5 \mathrm{~m} \times 7.5 \mathrm{~m})$ were moldboard plowed on 5 April 1992 and on 14 April 1993, prior to planting peanut. Treatments included: 1) bahiagrass-peanut-peanut; 2) bahiagrass-bahiagrass-peanut; 3) continuous peanut; and 4) continuous peanut + flutolanil in 1992. The following season, treatments were : 1) bahiagrass-peanut-peanut-peanut; 2) bahiagrass-bahiagrass-peanutpeanut; 3) bahiagrass-bahiagrass-bahiagrass-peanut; 4) continuous peanut; and 5) continuous peanut + flutolanil each year. Flutolanil was applied at a rate of $2.24 \mathrm{~kg}$ a.i. ha ${ }^{-1}$ on the same dates as the GF2 trial. All treatments were replicated four times. Cultural practices and fertilization rates were determined using standard practices (Johnson et al. 1987). Peanuts were inverted on 9 and 30 September in 1992 and in 1993 and harvested by combine after drying in the field. Detached pods were collected from the previously harvested plots on 14 October for both years.

\section{Laboratory procedures}

Fifty pods from each field plot were dried in the laboratory to approximately $12 \%$ (w:w) moisture, placed into paper bags, boxed, and shipped by overnight mail to the laboratory, in Vincennes, Indiana. When received, the box was opened and the bags were stored at room temperature. In December 1992 and 1993, halfshells of 20 pods plot $^{-1}$ arbitrarily selected from each location were assayed for mycobiota diversity. Pods were opened by hand and one half-shell of each pod was used for the assay. The half-shells were surface sterilized with $0.52 \%$ (w:v) aqueous sodium hypochlorite solution for 5 $\mathrm{min}$. The half-shells were placed on maltextract agar (MEA) containing $6 \mathrm{mg} \mathrm{L}^{-1}$ dicloran (2,6-dichloro-4-nitroaniline) and malt-salt agar (MSA) in $9-\mathrm{cm}$ diameter petri dishes (Baird et al. 1991, 1993c). Ten half-shells from each replicate plot were plated onto each medium and incubated at room temperature $\left(21-25^{\circ} \mathrm{C}\right)$ for $10 \mathrm{~d}$. All fungi growing from shells were subcultured and plated onto potato-dextrose agar medium (PDA) for identification using macroscopic and microscopic morphological characteristics. Isolation frequencies were determined for each genus and species of fungus isolated (i.e. the percentage of total isolations for each trial and year.)

\section{Statistical analysis}

An analysis of variance of the actual and square-root transformed values of the isolation frequencies was performed to evaluate the effects of rotations and fungicide treatment (SAS Institute Inc. 1985). Whichever variable gave the best result (greatest $F$ value) was used for reporting. Fisher's LSD was used to separate means. Total fungi refer to all isolations for species and genera.

\section{RESULTS AND DISCUSSION}

A total of 11343 fungal isolates from 31 genera were obtained from peanut halfshells collected in all three locations for both years of the study (Table 1). For the Gibbs Farm in trial 1, 943 isolates were obtained in 1992, and 1788 isolates in 1993. In trial 2, 1482 isolates were obtained in 1992 and 3900 in 1993 . At the Blackshank Farm, 1109 isolates were obtained in 1992 and 2121 in 1993. More than two-thirds of the isolates were from the Deuteromycotina, followed in frequency by the Basidiomycetes, Ascomycetes, and Phycomycetes (Table 1). Similar percentages of fungal species were cultured from peanut shells in previous research (Baird et al. 1993b,c). Rotation practices influenced the isolation rates of several fungal species in all field trials for both years. The differences, however, were not consistent for each fungus and specific management practice. 
Table 1. Incidence of recovery of fungal genera from shells of peanut cv. Florunner collected from three rotation field trials at two farms near Tifton, Georgia

\begin{tabular}{|c|c|c|c|c|c|c|}
\hline \multirow[b]{4}{*}{ Fungal genera } & \multicolumn{6}{|c|}{ Incidence of recovery ${ }^{a}(\%)$} \\
\hline & \multicolumn{4}{|c|}{ Gibbs Farm } & \multirow{2}{*}{\multicolumn{2}{|c|}{$\frac{\text { Blackshank Farm }}{\text { Trial } 1}$}} \\
\hline & \multicolumn{2}{|c|}{ Trial 1} & \multicolumn{2}{|c|}{ Trial 2} & & \\
\hline & 1992 & 1993 & 1992 & 1993 & 1992 & 1993 \\
\hline Alternaria & 15.7 & 21.1 & 18.4 & 23.9 & 5.1 & 8.5 \\
\hline Aspergillus & 0 & $<1.0$ & $<1.0$ & $<1.0$ & $<1.0$ & $<1.0$ \\
\hline Bipolaris & 0 & 0 & 0 & $<1.0$ & $<1.0$ & $<1.0$ \\
\hline Lasiodiplodia & 1.2 & 0 & 4.9 & 4.2 & $<1.0$ & 1.3 \\
\hline Cephalosporium & 0 & 2.9 & 0 & $<1.0$ & 0 & $<1.0$ \\
\hline Chaetomella & 0 & 0 & 0 & $<1.0$ & 0 & 0 \\
\hline Chaetomium & $<1.0$ & 0 & 0 & $<1.0$ & 0 & 0 \\
\hline Cladosporium & 0 & $<1.0$ & 0 & $<1.0$ & 0 & 0 \\
\hline Colletotrichum & 0 & 0 & 0 & 0 & 0 & $<1.0$ \\
\hline Cumminghamella & 0 & 0 & 0 & $<1.0$ & 0 & 0 \\
\hline Curvularia & 0 & $<1.0$ & 0 & 2.2 & 0 & 2.7 \\
\hline Cylindrocladium & $<1.0$ & 0 & $<1.0$ & $<1.0$ & 1.0 & 1.1 \\
\hline Diheterospora & $<1.0$ & 0 & 0 & 0 & $<1.0$ & $<1.0$ \\
\hline Epicoccum & $<1.0$ & $<1.0$ & $<1.0$ & $<1.0$ & 0 & $<1.0$ \\
\hline Fusarium & 46.3 & 45.2 & 51.3 & 46.6 & 56.4 & 51.2 \\
\hline Gliocladium & 5.8 & 0 & 2.0 & $<1.0$ & 1.7 & $<1.0$ \\
\hline Gliomaxis & 0 & 0 & 0 & $<1.0$ & 0 & 0 \\
\hline Helminthosporium & $<1.0$ & 0 & 0 & 0 & $<1.0$ & $<1.0$ \\
\hline Humicola & $<1.0$ & 0 & 0 & $<1.0$ & 0 & $<1.0$ \\
\hline Macrophomina & 2.8 & $<1.0$ & $<1.0$ & $<1.0$ & 1.2 & 0 \\
\hline Mucor & $<1.0$ & $<1.0$ & 3.0 & $<1.0$ & 1.7 & 0 \\
\hline Neocosmospora & $<1.0$ & $<1.0$ & $<1.0$ & $<1.0$ & $<1.0$ & $<1.0$ \\
\hline Nigrospora & 3.7 & 6.3 & 3.8 & 5.4 & 11.1 & 1.9 \\
\hline Papulosa & $<1.0$ & 0 & $<1.0$ & 0 & 0 & 0 \\
\hline Penicillium & 0 & $<1.0$ & $<1.0$ & $<1.0$ & $<1.0$ & 0 \\
\hline Pestalotia & 0 & 0 & $<1.0$ & $<1.0$ & $<1.0$ & $<1.0$ \\
\hline Phoma & $<1.0$ & $<1.0$ & $<1.0$ & $<1.0$ & $<1.0$ & $<1.0$ \\
\hline Pithomyces & 0 & 0 & 0 & 0 & $<1.0$ & 0 \\
\hline Pythium & $<1.0$ & $<1.0$ & $<1.0$ & $<1.0$ & 1.4 & $<1.0$ \\
\hline Rhizoctonia & 8.2 & 9.8 & 8.3 & 5.9 & 9.9 & 7.8 \\
\hline Rhizopus & 2.0 & $<1.0$ & $<1.0$ & 1.2 & 4.2 & 3.3 \\
\hline Sclerotium & 0 & $<1.0$ & $<1.0$ & $<1.0$ & 0 & $<1.0$ \\
\hline Sphaeropsis & 0 & 0 & 0 & 0 & $<1.0$ & 0 \\
\hline Theilavia & 0 & $<1.0$ & 0 & $<1.0$ & 0 & 0 \\
\hline Trichoderma & 12.1 & 7.9 & 5.0 & 4.8 & 3.8 & 5.6 \\
\hline
\end{tabular}

a Number of isolates on which mean percent isolation values are based : 943 in 1992, 1788 in 1993 for Gibbs Farm Trial 1; 1482 in 1992, 3900 in 1993 for Gibbs Farm Trial 2; 1109 in 1992, 2121 in 1993 for Blackshank Farm Trial 1.

There was an interaction between rotations and cover crop for several of the fungi (Table 2). Analyzation of the isolation frequencies generally results in observing considerable error variance due to the variability among the various plots being sampled. For some of the fungi, the square-root transformation was able to show differences among the means. When these counts were moderate in size, differences among means were determined with the actual data. However, when the counts were large, the possibility of extra variability increased because some counts were zero causing the differences among means to be non-significant. Data under this condition is shown if at least $10 \%$ of the total fungi count was involved. In the GF1 trial in 1992, isolation frequencies on MSA of several fungal species and of total fungi from halfshells collected in plots with a rye cover crop differed from those plots with no cover crop in both the cotton-peanut and 
Table 2. Comparison of interactive effects of two crop rotations, with and without a rye cover crop, on mean isolation frequencies of fungi in peanut shells from the Gibbs Farm, trial GF1, in 1992 and 1993

\begin{tabular}{|c|c|c|c|c|c|}
\hline \multirow[b]{3}{*}{ Fungia $^{a}$} & \multirow[b]{3}{*}{ Medium } & \multicolumn{4}{|c|}{ Rotation } \\
\hline & & \multicolumn{2}{|c|}{ Cotton-Peanut } & \multicolumn{2}{|c|}{ Continuous Peanut } \\
\hline & & no rye & rye & no rye & rye \\
\hline \multicolumn{6}{|l|}{1992} \\
\hline Alternaria alternata & MSA & $5.8 \mathrm{~b}^{\mathrm{b}}$ & $3.8 \mathrm{a}$ & $16.0 \mathrm{a}$ & $7.5 \mathrm{a}$ \\
\hline Fusarium equisiti & MEA & $8.5 \mathrm{a}$ & $7.5 \mathrm{a}$ & $7.5 \mathrm{a}$ & $3.8 \mathrm{a}$ \\
\hline Fusarium equisiti & MSA & $13.0 \mathrm{a}$ & $23.5 \mathrm{a}$ & $20.5 \mathrm{a}$ & $9.0 \mathrm{~b}$ \\
\hline Fusarium graminearum ${ }^{+c}$ & MEA & $0 \quad b$ & $2.0 \mathrm{a}$ & $2.0 \mathrm{a}$ & $0 \mathrm{~b}$ \\
\hline Fusarium oxysporum & MSA & $0.5 \mathrm{~b}$ & $1.0 \mathrm{a}$ & $0.9 \mathrm{a}$ & $0.5 \mathrm{a}$ \\
\hline Gliocladium spp. & MEA & $3.3 \mathrm{a}$ & $1.5 \mathrm{a}$ & $4.5 \mathrm{a}$ & $4.5 \mathrm{a}$ \\
\hline Neocosmospora vasinfecta ${ }^{+}$ & MSA & $0.5 \mathrm{a}$ & $0.8 \mathrm{a}$ & $1.0 \mathrm{a}$ & $0.5 \mathrm{~b}$ \\
\hline Rhizoctonia solani AG-4 & MEA & $3.5 \mathrm{a}$ & $3.8 \mathrm{a}$ & $2.5 \mathrm{a}$ & $1.8 \mathrm{a}$ \\
\hline Rhizoctonia solani $\mathrm{CAG}-3^{+}$ & MEA & $0.5 \mathrm{~b}$ & $1.7 \mathrm{a}$ & $0.5 \mathrm{a}$ & $0.7 \mathrm{a}$ \\
\hline Trichoderma spp. & MEA & $7.8 \mathrm{a}$ & $4.3 \mathrm{a}$ & $4.5 \mathrm{a}$ & $4.5 \mathrm{a}$ \\
\hline Total fungi & MEA & $32.3 \mathrm{a}$ & 35.8 a & $37.8 \mathrm{a}$ & $26.8 \mathrm{~b}$ \\
\hline Total fungi & MSA & $18.8 \mathrm{~b}$ & $42.3 \mathrm{a}$ & 29.5 a & $12.8 \mathrm{~b}$ \\
\hline \multicolumn{6}{|l|}{1993} \\
\hline Alternaria alternata & MEA & 5.5 a & $3.0 \mathrm{a}$ & $4.5 \mathrm{a}$ & $5.0 \mathrm{a}$ \\
\hline Alternaria alternata & MSA & $22.3 \mathrm{a}$ & $17.8 \mathrm{a}$ & $18.3 \mathrm{a}$ & $18.3 \mathrm{a}$ \\
\hline Aspergillus niger & MEA & $2.0 \mathrm{a}$ & $0 \quad b$ & $0 \quad a$ & 0 a \\
\hline Fusarium equisiti & MSA & 26.3 a & $24.0 \mathrm{a}$ & $17.8 \mathrm{a}$ & $2.4 .0 \mathrm{a}$ \\
\hline Fusarium oxysporum & MEA & $10.8 \mathrm{a}$ & $12.8 \mathrm{a}$ & $14.8 \mathrm{a}$ & $14.3 \mathrm{a}$ \\
\hline Fusarium oxysporum & MSA & $6.8 \mathrm{a}$ & $10.3 \mathrm{a}$ & $7.0 \mathrm{a}$ & $13.5 \mathrm{a}$ \\
\hline Nigrospora sphaerica & MSA & $5.3 \mathrm{a}$ & $3.3 \mathrm{a}$ & $0.8 \mathrm{a}$ & $6.0 \mathrm{a}$ \\
\hline Rhizoctonia solani AG-4 & MEA & 5.8 a & $4.8 \mathrm{a}$ & $10.3 \mathrm{a}$ & $97.5 \mathrm{a}$ \\
\hline Trichoderma spp. & MEA & 10.5 a & $9.3 \mathrm{a}$ & $5.0 \mathrm{a}$ & 9.3 a \\
\hline Trichoderma spp. ${ }^{+}$ & MSA & 0.9 a & $0.5 \mathrm{a}$ & $0.5 \mathrm{~b}$ & $1.0 \mathrm{a}$ \\
\hline Total fungi & MEA & $51.5 \mathrm{a}$ & $41.0 \mathrm{a}$ & $53.8 \mathrm{a}$ & 54.8 a \\
\hline Total fungi & MSA & 63.8 a & $59.0 \mathrm{a}$ & $46.5 \mathrm{a}$ & 66.8 a \\
\hline
\end{tabular}

a Fungi included are those with large means (> 10\% of total) and those that were significantly different.

b Within a rotation, means for rye or no rye followed by the same letter are not significantly different $(P<0.05)$ according to Fisher's LSD.

${ }^{c} A+$ in a row indicates that square-root transformed data was used.

continuous peanut rotations (Table 2). Isolation frequencies for several of the fungi in this trial were significantly greater with a rye cover crop in the cottonpeanut rotation and lower in the continuous peanut rotation when shells were plated onto MEA. In the first year of the study, isolation frequencies for total fungi were greater in the cotton-peanut rotation with rye than in the same rotation without rye. However, the results were opposite in the continuous peanut plots, and no differences in isolation frequencies were observed when the study was repeated in 1993. Specific fungi affected were Alternaria alternata (Fr.:Fr.) Keissl., Fusarium graminearum Schwabe and $F$. oxysporum which were isolated more frequently from peanut shells in the presence of a rye cover crop than without rye in the cotton-peanut rotation in 1992. The opposite trend occurred in the continuous peanut rotation where Aspergillus niger Tiegh. was the only fungus which had significantly greater mean isolation values between the rye and no rye in 1993. Sumner et al. (1986) found that levels of certain soilborne fungi such as 
Pythium and Rhizoctonia are lowered when cover crops such as wheat and rye were used, but no differences in isolation frequencies of these fungi were observed between the rye and no rye plots in the GF1 trials.

There was no interaction between rotations and flutolanil for any of the fungi (Tables 3, 4). In the GF2 study, the crop rotations and fungicide treatments significantly affected the isolation frequencies of fungi from peanut shells. Tables 3-4 shows the results from the analysis of the effects of rotation practices and flutolanil on isolation frequencies using the two agar media. Rhizoctonia solani AG-4 was isolated more frequently $(P \leq 0.05)$ in the continuous peanut rotation than in the other treatments on MSA in 1993 (Table 4). Rhizoctonia solani AG-4 is a pathogen of cotton and peanuts, and higher frequencies of isolation were expected in the cotton-peanut rotation than in the bahiagrass-peanut rotation. Bahiagrass is not known to be a host of $R$. solani AG-4, and isolation frequencies of the pathogen did not increase during the first year. Rhizoctonia solani AG 2-2, a pathogen of other grass species
(Hurd and Grisham 1983; Oniki et al. 1986), was recovered at a significantly higher frequency in the bahiagrass-peanut rotation in 1992 than from the other rotations, but no differences in isolation frequencies were observed in 1993 (Tables $3,4)$. The isolation frequencies of $R$. solani AG 2-2 were low in the bahiagrasspeanut rotation in 1992, but the infrequent isolation of this pathotype during the second year prevented any rotation comparisons (data not shown). Rhizoctonia solani AG 2-2 causes root decay in corn (Sumner and Bell 1982) and it is uncertain why higher levels of the fungus were not found in the corn rotation in 1993. Macrophomina phaseolina (Tassi) Goidanich, a pathogen of soybean (Glycine max Merr.), was isolated more frequently in the bahiagrass-peanut rotation both years compared with the other rotations. Lasiodiplodia theobromae (Pat.) Giffon and Maubl., which causes boll rot and dieback in cotton seedlings (USDA 1960), was more prevalent in the cottonpeanut rotation. The genus Diplodia, which is morphologically similar to and possibly the same as Lasiodiplodia spp. was reported to cause brown spot of cotton (USDA 1960) and collar rot of

Table 3. Comparison of effects of crop rotations and a fungicide treatment on mean isolation frequencies of various fungi from peanut shells collected at the Gibbs Farm, trial GF2, in 1992

\begin{tabular}{|c|c|c|c|c|c|c|}
\hline \multirow[b]{3}{*}{ Fungi } & \multirow[b]{3}{*}{ Medium } & \multicolumn{5}{|c|}{$\begin{array}{c}\text { Mean isolation frequency } \\
(\%)\end{array}$} \\
\hline & & \multicolumn{3}{|c|}{ Rotation } & \multicolumn{2}{|c|}{ Treatment } \\
\hline & & $\mathrm{B}-\mathrm{P}^{\mathrm{b}}$ & CT-P & P-P & Flutolanil & Untreated \\
\hline Alternaria alternata & MEA & $11.1 \mathrm{a}^{\mathrm{c}}$ & $8.0 \mathrm{a}$ & $10.3 \mathrm{a}$ & $9.1 \mathrm{a}$ & $10.5 \mathrm{a}$ \\
\hline Fusarium equisiti $\mathrm{d}$ & MEA & $2.5 \mathrm{a}$ & $2.4 \mathrm{a}$ & $2.7 \mathrm{a}$ & $2.8 \mathrm{a}$ & $2.2 \mathrm{~b}$ \\
\hline Fusarium equisiti & MSA & $19.4 \mathrm{a}$ & 19.9 a & $20.4 \mathrm{a}$ & $21.2 \mathrm{a}$ & $18.6 \mathrm{a}$ \\
\hline $\begin{array}{l}\text { Gliocladium spp. } \\
\text { Lasiodiplodia }\end{array}$ & MEA & $1.1 \mathrm{a}$ & 0.9 a & $1.2 \mathrm{a}$ & $0.6 \mathrm{~b}$ & $1.6 \mathrm{a}$ \\
\hline $\begin{array}{l}\text { theobromae } \\
\text { Rhizoctonia solani }\end{array}$ & MEA & $1.6 \mathrm{~b}$ & $2.4 \mathrm{a}$ & $0.9 \mathrm{c}$ & $1.8 \mathrm{a}$ & $1.5 \mathrm{a}$ \\
\hline AG 2-2 & MEA & $0.6 \mathrm{a}$ & $0 \quad b$ & $0 \mathrm{~b}$ & $0.3 \mathrm{a}$ & $0.1 \mathrm{a}$ \\
\hline Trichoderma spp.+ & MEA & $1.9 \mathrm{a}$ & $1.3 \mathrm{a}$ & $1.6 \mathrm{a}$ & $1.2 \mathrm{~b}$ & $2.0 \mathrm{a}$ \\
\hline Total fungi & MEA & $31.1 \mathrm{a}$ & $27.3 \mathrm{a}$ & $31.0 \mathrm{a}$ & $28.3 \mathrm{a}$ & $31.3 \mathrm{a}$ \\
\hline Total fungi & MSA & $32.1 \mathrm{a}$ & $31.0 \mathrm{a}$ & $32.6 \mathrm{a}$ & $31.8 \mathrm{a}$ & $32.1 \mathrm{a}$ \\
\hline
\end{tabular}

\footnotetext{
a Means of all rotations; rotation means were averaged over treatments, and treatment means were averaged over rotation. Fungi included are those with large ( $>10 \%$ of total) means and those that were significantly different.

${ }^{b}$ Crop rotations for 1992 : $\mathrm{B}-\mathrm{P}=$ bahiagrass-peanut, $\mathrm{CT}-\mathrm{P}=$ cotton-peanut, and $\mathrm{P}-\mathrm{P}=$ continuous peanut.

c Rotation or treatment values in a row followed by the same letter are not significantly different $(P<0.05)$ according to Fisher's LSD.

${ }^{d} A+$ indicates that square-root transformed data was used.
} 
Table 4. Comparison of effects of crop rotations and a fungicide treatment on mean isolation frequencies of various fungi from peanut shells collected at the Gibbs Farm, trial GF2, in 1993

\begin{tabular}{|c|c|c|c|c|c|c|c|}
\hline \multirow[b]{3}{*}{ Fungi } & \multirow[b]{3}{*}{ Medium } & \multicolumn{6}{|c|}{$\begin{array}{c}\text { Mean isolation frequency } \\
(\%)\end{array}$} \\
\hline & & \multicolumn{4}{|c|}{ Rotation } & \multicolumn{2}{|c|}{ Treatment } \\
\hline & & B-B-Pb & C-C-P & CT-CT-P & P-P-P & Flutolanil & Untreated \\
\hline \multicolumn{8}{|l|}{ Alternaria } \\
\hline $\begin{array}{l}\text { alternata } \\
\text { Alternaria }\end{array}$ & MEA & $7.3 \mathrm{a}^{\mathrm{c}}$ & $8.4 \mathrm{a}$ & $5.6 \mathrm{a}$ & $4.3 \mathrm{a}$ & $5.8 \mathrm{a}$ & $6.9 \mathrm{a}$ \\
\hline $\begin{array}{c}\text { alternata } \\
\text { Cladosporium }\end{array}$ & MSA & $23.4 a b$ & $25.5 \mathrm{a}$ & 25.8 a & $16.3 \mathrm{~b}$ & 25.8 a & $19.6 \mathrm{~b}$ \\
\hline spp. & MSA & $0.5 \mathrm{a}$ & $1.0 \mathrm{a}$ & $0.8 \mathrm{a}$ & $0.3 \mathrm{a}$ & $1.0 \mathrm{a}$ & $0.3 \mathrm{~b}$ \\
\hline Curvularia spp. ${ }^{+d}$ & MEA & $1.3 \mathrm{a}$ & $1.7 \mathrm{a}$ & $1.2 \mathrm{ab}$ & $0.7 \mathrm{~b}$ & $1.4 \mathrm{a}$ & $1.0 \mathrm{~b}$ \\
\hline Epicoccum spp. ${ }^{+}$ & MEA & $0.7 \mathrm{a}$ & $0.6 \mathrm{a}$ & $0.5 \mathrm{a}$ & $0.6 \mathrm{~b}$ & $0.6 \mathrm{~b}$ & $0.9 \mathrm{a}$ \\
\hline $\begin{array}{l}\text { Fusarium equisiti } \\
\text { Fusarium }\end{array}$ & MEA & 9.8 a & $6.4 \mathrm{a}$ & $4.1 \mathrm{a}$ & $5.4 \mathrm{a}$ & 5.9 a & 6.9 a \\
\hline $\begin{array}{l}\text { oxysporum } \\
\text { Fusarium }\end{array}$ & MEA & 14.6 a & $17.1 \mathrm{a}$ & 15.1 a & 18.6 a & $17.4 \mathrm{a}$ & 15.3 a \\
\hline $\begin{array}{l}\text { sambucinum }^{+} \\
\text {Lasiodiplodia }\end{array}$ & MSA & $1.2 \mathrm{a}$ & $1.3 \mathrm{a}$ & $0.9 \mathrm{ab}$ & $0.6 \mathrm{~b}$ & $1.1 \mathrm{a}$ & 0.9 a \\
\hline $\begin{array}{l}\text { theobromae } \\
\text { Lasiodiplodia }\end{array}$ & MEA & $3.0 \mathrm{~b}$ & $2.0 \mathrm{~b}$ & $7.3 \mathrm{a}$ & $1.3 \mathrm{~b}$ & 3.9 a & $2.8 \mathrm{a}$ \\
\hline $\begin{array}{c}\text { theobromae } \\
\text { Neocosmospora }\end{array}$ & MSA & $0.8 \mathrm{~b}$ & $1.0 \mathrm{~b}$ & 1.9 a & $0.8 \mathrm{~b}$ & $1.2 \mathrm{a}$ & $1.1 \mathrm{a}$ \\
\hline $\begin{array}{l}\text { vasinfecta } \\
\text { Nigrospora }\end{array}$ & MEA & $1.0 \mathrm{ab}$ & $0.5 \mathrm{~b}$ & $1.1 \mathrm{a}$ & $1.3 \mathrm{a}$ & $1.0 \mathrm{a}$ & $0.9 \mathrm{a}$ \\
\hline $\begin{array}{l}\text { sphaerica } \\
\text { Nigrospora }\end{array}$ & MEA & $4.3 \mathrm{a}$ & $3.8 \mathrm{a}$ & 3.6 a & $2.6 \mathrm{a}$ & $3.7 \mathrm{a}$ & $3.4 \mathrm{a}$ \\
\hline $\begin{array}{l}\text { sphaerica } \\
\text { Rhizoctonia solani }\end{array}$ & MSA & $2.1 \mathrm{a}$ & $2.4 \mathrm{a}$ & $5.1 \mathrm{a}$ & $2.6 \mathrm{a}$ & 3.1 a & $3.0 \mathrm{a}$ \\
\hline $\begin{array}{l}\text { AG-4 } 4^{+} \\
\text {Rhizoctonia solani }\end{array}$ & MEA & $2.0 \mathrm{a}$ & $1.8 \mathrm{a}$ & $2.7 \mathrm{a}$ & $2.3 \mathrm{a}$ & $2.6 \mathrm{a}$ & $1.8 \mathrm{~b}$ \\
\hline $\begin{array}{c}\text { AG-4 } \\
\text { Rhizopus }\end{array}$ & MSA & $0 \quad b$ & $0 \mathrm{~b}$ & $0.3 \mathrm{~b}$ & $0.8 \mathrm{a}$ & $0.2 \mathrm{a}$ & $0.3 \mathrm{a}$ \\
\hline stolonifer ${ }^{+}$ & MEA & 0.7 a & 0.9 a & 0.8 a & $0.5 \mathrm{a}$ & 0.9 a & $0.5 \mathrm{~b}$ \\
\hline $\begin{array}{l}\text { Total fungi } \\
\text { Total fungi }\end{array}$ & MEA & $61.1 \mathrm{a}$ & 61.6 a & 58.5 a & 53.9 a & 58.1 a & 59.4 a \\
\hline folal tungi & IVISA & $00.4 \mathrm{dD}$ & $10.5 \mathrm{a}$ & 06.9 a & $54.6 \mathrm{a}$ & 69.1 a & $57.2 \mathrm{~b}$ \\
\hline
\end{tabular}

a Means of all rotations; rotation means were averaged over treatments, and treatment means were averaged over rotation. Fungi included are those with large ( $>10 \%$ of total) means and those that were significantly different.

b Crop rotations for 1993 : B-B-P = bahiagrass-bahiagrass-peanut, $C-C-P=$ corn-corn-peariut, CT$\mathrm{CT}-\mathrm{P}=$ cotton-cotton-peanut, and P-P-P = continuous peanut.

c Rotation or treatment values in a row followed by the same letter are not significantly different $(P<0.05)$ according to Fisher's LSD.

d $A+$ indicates that square-root transformed data was used.

peanut (Jackson and Bell 1969). The presence of cotton in the rotation may have been the cause of the increased isolation frequencies of Lasiodiplodia in the 1992 and 1993 field trials. During the second field season alone, isolation frequencies of $A$. alternata, Fusarium sambucinum Fuckel, Neocosmospora vasinfecta E.F. Sm., and Trichoderma spp. were influenced by rotation practice ( $\mathrm{Ta}$ ble 4). Rotational effects on isolation frequencies varied among those four species. Alternaria alternata, which is not parasitic, but saprophytic on cotton or corn in Georgia, was isolated more frequently from the corn-corn-peanut treatment. Trichoderma spp., often used in biological control tests, were isolated at a similar levels from all the rotations in 1992 (Table 3). Isolation frequencies for $F$. sambucinum and $N$. vasinfectawere low $(<1 \%)$ in all rotations. Neocosmospora vasinfecta is considered a minor pathogen on peanut (Baard and Van Wyk 
1985; Huang et al. 1992) and isolations were greatest from continuous peanut than in the other treatments. In vitro however, $N$. vasinfecta var. africana was documented to be antagonistic to 14 important pathogenic soilborne fungi (Turhan and Grossmann 1988).

There were no interactions between rotations and flutolanil for any of the fungi. No differences were found in isolation frequencies of the fungi isolated from half-shells in the flutolanil-treated plots compared to the untreated controls in both years in the GF1 trial. When results from the flutolanil treated versus untreated control plots were compared in the GF2 trial isolation frequencies for three fungi did differ significantly $(P \leq 0.05)$ in 1992 (Table 3). Gliocladium spp., Fusarium equisiti (Corda) Sacc. and Trichoderma spp. were isolated less frequently in the flutolanil treated plots than in the untreated control, but no differences were observed for R. solani AG-2-2 in 1992 and AG-4 in 1993. Previous research has shown that flutolanil applications occasionally, but not always, resulted in a lower isolation frequency for $R$. solani anastomosis groups from peanut shells
(Baird et al. 1993a,b). In the 1993 GF2 trial, isolation frequencies of five species of fungi, including the pathogens $R$. solani AG-4 and $R$. stolonifer were greater in the flutolanil-treated plots in 1993, presumably because the fungicide altered the natural microflora.

Significant differences in isolation frequency on the two media were observed for three species of fungi evaluated in 1992 and eight species in 1993. Alternaria alternata and $F$. equisiti were isolated more frequently from half-shells on MSA than from those on MEA in both years. Previous research has shown that MSA is excellent for isolation of certain species of Alternaria and Fusarium (Baird et al. 1993b). Nigrospora sphaerica (Sacc.) E. Mason is favored by MEA (Baird et al. 1993b). More fungal isolates were obtained on MSA than on MEA in 1992, but isolation frequencies on the two media were similar in 1993.

Within individual rotations, eight (1992) and nine (1993) fungal species were isolated at significantly different frequencies from half-shells collected at the Blackshank Farm (Tables 5, 6). In 1992 ,

Table 5. Comparison of effects of four rotation practices using two media on mean isolation frequencies of various fungi from peanut shells collected at the Blackshank Farm, trial BF1, in 1992

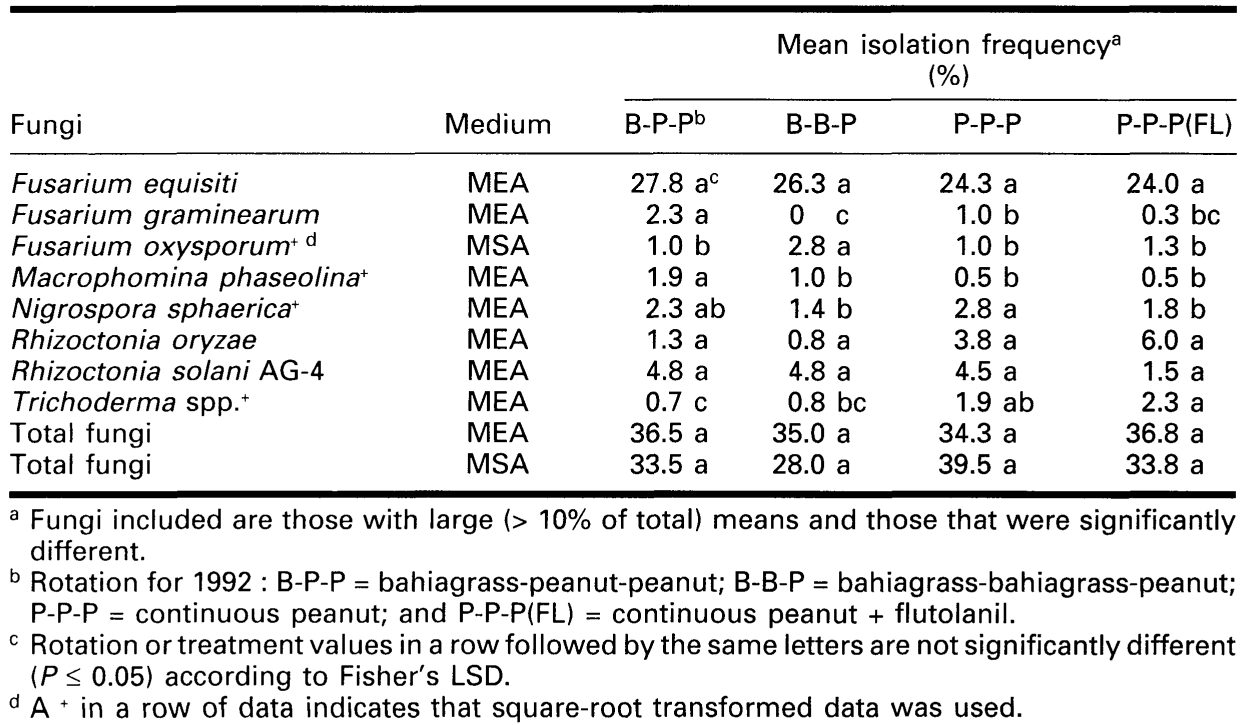


Table 6. Comparison of effects of four rotation practices using two media on mean isolation frequencies of various fungi from peanut shells collected at the Blackshank Farm, trial EBF1, in 1993

Mean isolation frequency ${ }^{a}$

$(\%)$

Fungi

Medium B-P-P-Pb B-B-P-P B-B-B-P P-P-P-P B-P-B-P P-P-P-P (FL)

\begin{tabular}{|c|c|c|c|c|c|c|c|}
\hline Alternaria alternata ${ }^{+} \mathrm{c}$ & MSA & $3.5 \mathrm{a}^{\mathrm{d}}$ & $3.2 a b$ & $4.1 \mathrm{a}$ & $2.4 \mathrm{~b}$ & 3.9 a & $3.1 \mathrm{ab}$ \\
\hline Cephalosporium spp. & MEA & $0 \quad b$ & $0 \mathrm{~b}$ & $0.5 \mathrm{a}$ & $0 b$ & $0 \mathrm{~b}$ & $0 b$ \\
\hline Diheterospora spp. & MSA & $0 \quad b$ & $0 \quad b$ & $0.3 \mathrm{~b}$ & $0 \quad b$ & $0.3 \mathrm{~b}$ & $1.0 \mathrm{a}$ \\
\hline Fusarium equisiti & MEA & $3.8 \mathrm{a}$ & $4.5 \mathrm{a}$ & $4.0 \mathrm{a}$ & $5.0 \mathrm{a}$ & $4.5 \mathrm{a}$ & $5.5 \mathrm{a}$ \\
\hline Fusarium equisiti & MSA & $6.0 \mathrm{a}$ & $11.8 \mathrm{a}$ & $6.8 \mathrm{a}$ & $4.3 \mathrm{a}$ & $10.0 \mathrm{a}$ & $9.3 \mathrm{a}$ \\
\hline Fusarium oxysporum & MEA & $8.8 \mathrm{a}$ & $5.8 \mathrm{a}$ & $5.8 \mathrm{a}$ & $7.8 \mathrm{a}$ & $8.5 \mathrm{a}$ & $10.3 \mathrm{a}$ \\
\hline Fusarium oxysporum & MSA & $7.0 \mathrm{a}$ & $4.5 \mathrm{a}$ & $9.5 \mathrm{a}$ & $13.3 \mathrm{a}$ & $6.0 \mathrm{a}$ & $9.3 \mathrm{a}$ \\
\hline Fusarium solani & MEA & $6.8 \mathrm{a}$ & $11.5 \mathrm{a}$ & $9.8 \mathrm{a}$ & $5.0 \mathrm{a}$ & $10.0 \mathrm{a}$ & $4.3 \mathrm{a}$ \\
\hline Rhizoctonia solani AG-4 & MEA & $5.0 \mathrm{a}$ & $7.8 \mathrm{a}$ & $6.3 \mathrm{a}$ & $5.8 \mathrm{a}$ & $6.5 \mathrm{a}$ & $3.3 \mathrm{a}$ \\
\hline Rhizopus stolonifer & MEA & $0.3 \mathrm{~b}$ & $0 \mathrm{~b}$ & $1.0 \mathrm{a}$ & $0 \mathrm{~b}$ & & \\
\hline Trichoderma spp. $^{+}$ & MEA & $2.8 \mathrm{a}$ & $2.0 \mathrm{a}$ & $2.5 \mathrm{a}$ & $2.6 \mathrm{a}$ & $1.4 a b$ & $0.5 \mathrm{~b}$ \\
\hline Total fungi & MEA & $41.3 \mathrm{a}$ & $42.8 \mathrm{a}$ & $47.0 \mathrm{a}$ & $45.5 \mathrm{a}$ & $51.0 \mathrm{a}$ & $44.0 \mathrm{a}$ \\
\hline Total fungi & MSA & $35.8 \mathrm{~cd}$ & 45.5 a-c & $57.3 \mathrm{a}$ & $30.8 d$ & $49.3 a b$ & $41.0 \mathrm{~b}-\mathrm{d}$ \\
\hline
\end{tabular}

a Fungi included are those with large (> 10\% of total) means and those that were significantly different.

${ }^{b}$ Rotations for 1993 : B-P-P-P = bahiagrass-peanut-peanut-peanut, B-B-P-P = bahiagrass-bahiagrass-peanut-peanut, $B-B-B-P=$ bahiagrass-bahiagrass-bahiagrass-peanut, $P-P-P-P=$ continuous peanut, $B-P-B-P=$ bahiagrass-peanut-bahiagrass-peanut, $P-P-P-P(F L)=$ continuous peanut + flutolanil.

${ }^{c} \mathrm{~A}+$ in a row of data indicates that square-root transformed data was used.

d Rotation or treatment values in a row followed by the same letters are not significantly different $(P \leq 0.05)$ according to Fisher's LSD.

F. graminearum and M. phaseolina were isolated at a significantly greater level in the bahiagrass-peanut-peanut rotation. Isolation frequencies of $R$. solani AG-4 did not differ for either year. However, AG-4 was isolated less frequently when flutolanil was applied, but the differences were not significant among the rotations. Fusarium oxysporum was common in the bahiagrass-bahiagrass-peanut rotation, and N. sphaerica was abundant in the continuous peanut rotation, but the isolation frequencies for 1993 did not differ among rotations. Trichoderma populations were greater $(P \leq 0.05)$ without flutolanil compared to the treated plots in 1993. The results were not comparable with the GF2 study shown in Tables 7 and 8 . When flutolanil was used in the continuous peanut plots the isolation frequencies of this fungus were lower $(P \leq 0.05)$ in 1993 . The positive effect of using the chemical for protection of the peanut crop from serious fungal patho- gens can be dramatic (Brenneman 1992) but if the fungicide reduces colonization of peanut shells by Trichoderma spp. and Gliocladium spp., their natural biocontrol activity against soilborne pathogens could be adversely affected (Papavizas 1985).

There was an interaction between rotations and cover crop for several fungi (Tables 7, 8). Differences among crop rotations and the flutolanil or non-flutolanil treatments were significant for four genera in 1992 and six in 1993 at the GF2 trial (Tables 7, 8). The 1992 mean isolation frequencies of Mucor spp. were greater in bahiagrass-peanut plots treated with flutolanil than those that were not treated, but the levels were too low to compare in 1993 (Table 8). Rhizoctonia solani AG-4 levels were relatively low in the bahiagrass-peanut rotations, but higher in the cotton-peanut and continuous peanut rotations and levels of the pathogen decreased with flutolanil use in 
Table 7. Interactive effects of crop rotations and flutolanil treatment on mean isolation frequencies of various fungi from peanut shells collected at the Gibbs Farm, trial GF2, in 1992

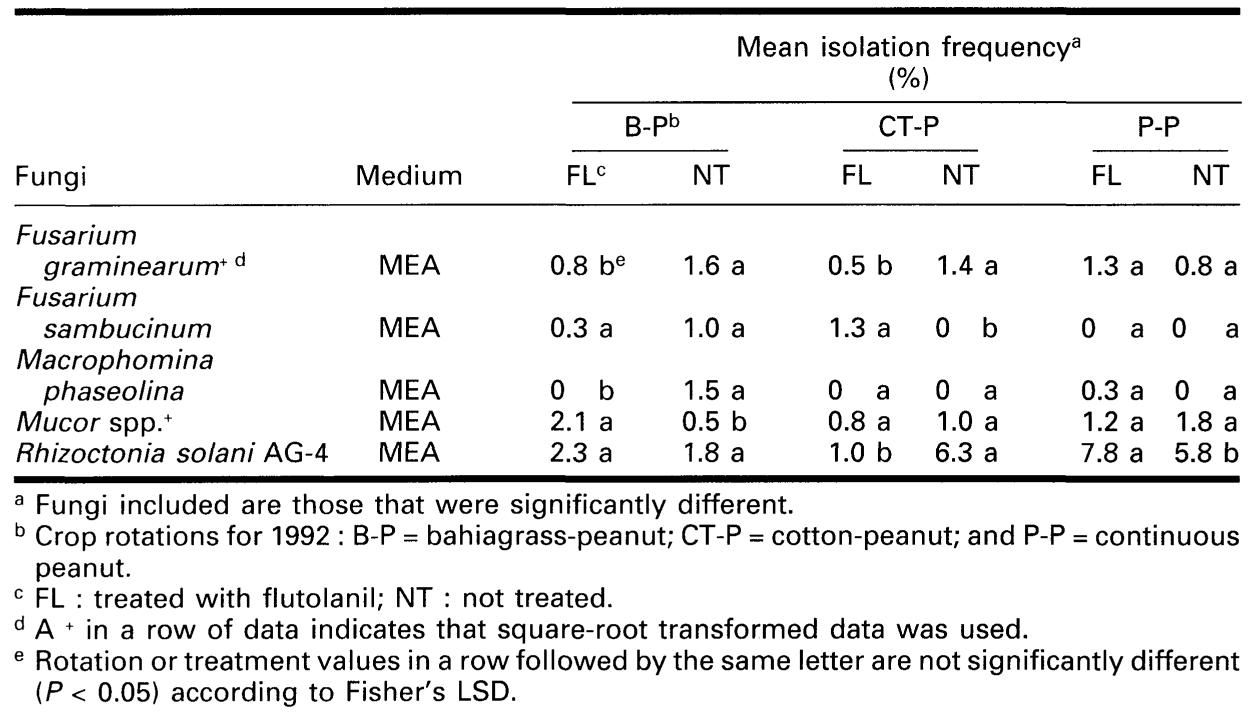

Table 8. Interactive effects of crop rotations and flutolanil treatment on mean isolation frequencies of various fungi from peanut shells collected at the Gibbs Farm, trial GF2 in 1993

\begin{tabular}{|c|c|c|c|c|c|c|c|c|c|}
\hline \multirow[b]{3}{*}{ Fungi } & \multirow[b]{3}{*}{ Medium } & & \multicolumn{7}{|c|}{$\begin{array}{l}\text { Mean isolation frequency } \\
(\%)\end{array}$} \\
\hline & & \multicolumn{2}{|c|}{ B-B-Pb } & \multicolumn{2}{|c|}{ C-C-P } & \multicolumn{2}{|c|}{ CT-CT-P } & \multicolumn{2}{|c|}{ P-P-P } \\
\hline & & $\mathrm{FL}^{\mathrm{c}}$ & NT & $\mathrm{FL}$ & NT & $\mathrm{FL}$ & NT & $\mathrm{FL}$ & NT \\
\hline \multicolumn{10}{|l|}{ Fusarium } \\
\hline $\begin{array}{l}\text { equisitit d }^{\text {equarium }} \\
\text { Fusarion }\end{array}$ & MSA & $4.8 \mathrm{a}^{\mathrm{e}}$ & $4.1 \mathrm{a}$ & $5.3 \mathrm{a}$ & $5.4 \mathrm{a}$ & $4.4 \mathrm{a}$ & $4.6 \mathrm{a}$ & $5.3 \mathrm{a}$ & $3.2 \mathrm{~b}$ \\
\hline oxysporum & MSA & $8.8 \mathrm{a}$ & $6.3 \mathrm{a}$ & $8.0 \mathrm{a}$ & $7.5 \mathrm{a}$ & $6.0 \mathrm{a}$ & $7.8 \mathrm{a}$ & $6.3 \mathrm{~b}$ & $16.5 \mathrm{a}$ \\
\hline $\begin{array}{l}\text { Mucor spp. } \\
\text { Penicillium }\end{array}$ & MEA & $0.5 \mathrm{a}$ & $0 \quad a$ & 0 a & $0 \quad a$ & $0 \mathrm{~b}$ & $1.0 \mathrm{a}$ & 0 a & 0 a \\
\hline $\begin{array}{l}\text { spp. } \\
\text { Sclerotium }\end{array}$ & MEA & $0 \quad a$ & $0.3 \mathrm{a}$ & 0 a & 0 a & 0 a & $0 \quad a$ & $0.5 \mathrm{a}$ & $0 \mathrm{~b}$ \\
\hline rolfsii & MEA & 0 & $1.3 \mathrm{~b}$ & 0 & $1.3 \mathrm{~b}$ & $0.8 \mathrm{a}$ & $0.3 \mathrm{a}$ & $0.8 \mathrm{a}$ & 0 \\
\hline $\begin{array}{l}\text { Theilavia spp. } \\
\text { Trichoderma }\end{array}$ & MEA & 0 & $0 \quad a$ & 0 & $4.3 \mathrm{a}$ & 0 a & $0 \quad a$ & 0 a & $0 \quad a$ \\
\hline spp. & MEA & $5.0 \mathrm{a}$ & $4.5 \mathrm{a}$ & $5.5 \mathrm{a}$ & $2.8 \mathrm{a}$ & $0.8 \mathrm{a}$ & $3.3 \mathrm{a}$ & $0.8 \mathrm{~b}$ & $19.8 \mathrm{a}$ \\
\hline
\end{tabular}

a Fungi included are those that were significantly different.

b Crop rotations for 1993 : B-B-P = bahiagrass-bahiagrass-peanut, C-C-P = corn-corn-peanut, CT$\mathrm{CT}-\mathrm{P}=$ cotton-cotton-peanut, and $\mathrm{P}-\mathrm{P}-\mathrm{P}=$ continuous peanut.

c FL : treated with flutolanil; NT : not treated.

d $A+$ in a row of data indicates that square-root transformed data was used.

e Rotation or treatment values in a row followed by the same letter are not significantly different $(P<0.05)$ according to Fisher's LSD. 
the cotton-peanut rotation but unexpectedly increased in the continuous peanut rotation. Isolation frequencies of $M$. phaseolina were greater from the bahiagrass-peanut rotation without flutolanil, indicating that the fungicide may have inhibited this pathogen, even though it is soilborne. Mean isolation rates of $M$. phaseolina in the other two rotations were low and did not differ significantly.

In 1993, mean isolation frequencies for $S$. rolfsii were significantly lower when flutolanil was used in the bahiagrassbahiagrass-peanut and corn-corn-peanut rotations (Table 8). For both years, isolation frequencies of $F$. oxysporum increased when flutolanil was applied and a large reduction in populations of Trichoderma in continuous peanut was documented in flutolanil treated plots in 1993. Flutolanil increased the mean isolation frequencies of $F$. equisiti and Penicillium spp. in the continuous peanut rotation. The increased frequency of these fungi may be the result of disruption of competitive microbes in the soil.

This investigation showed that both flutolanil and rotational practices can influence isolation frequencies of some fungi from peanut shells. Future studies should evaluate the effects of cultural practices and pesticides on populations of antagonistic fungi such as Trichoderma and Gliocladium as well as direct effects on populations of plant pathogenic fungi.

\section{REFERENCES}

Baard, S.W., and P.S. Van Wyk. 1985. Neocosmospora vasinfecta pathogenic to ground nuts in South Africa. Phytophylactia $17: 49-50$.

Baird, R.E., T.B. Brenneman, D.K. Bell, and A.P. Murphy. 1991. The effects of the fungicide propiconazole (Tilt®) on the groundnut shell mycobiota. Mycol. Res. $95: 571-586$.

Baird, R.E., D.K. Bell, D.R. Sumner, B.G. Mullinix, and A.K. Culbreath. 1993a. Survival of Rhizoctonia solani AG-4 in residual peanut shells in soil. Plant Dis. 77 : 973975.
Baird, R.E., T.B. Brenneman, D.K. Bell, A.K. Culbreath, and J.D. Moore. 1993b. The effects of the fungicide flutolanil (Moncut ${ }^{\circledR}$ ) on the peanut shell mycobiota of two peanut cultivars. Plant Dis. 77 : 736-741.

Baird, R.E., T.B. Brenneman, D.K. Bell, A.K. Culbreath, and B.G. Mullinix. 1993c. The peanut shell mycobiota of detached versus mechanically harvested pods either treated or nontreated with flutolanil. Plant Dis. 77 : 405-408.

Baird, R.E., D.R. Sumner, B.G. Mullinix C.C. Dowler, S.C. Phatak, A.W. Johnson, R.B. Chalfant, J.D. Gay, L.D. Chandler, and S.H. Baker. 1993d. Occurrence of fleshy fungi from agricultural fields. Mycopathologia $122: 29-34$

Bell, D.K., and D.R. Sumner. 1987. Survival of Rhizoctonia solani and other soilborne basidiomycetes in fallow soil. Plant Dis. $71: 911-915$.

Brenneman, T.B. 1992. Evaluation of experimental fungicides for the control of soilborne peanut pathogens, 1991. Fungicide and Nematicide Tests $47: 221$.

Hanlin, R.T. 1973. The distribution of peanut fungi in the southeastern United States. Mycopathol. Mycol. Appl. 49 : 227-241.

Huang, J., S. Chen, and W. Chung. 1992. Neocosmospora foot rot of peanut in Taiwan. Plant Pathol. Bull. 1 : 203-205.

Hurd, B., and M.P. Grisham. 1983. Rhizoctonia spp. associated with brown patch of St. Augustine grass. Phytopathology 73 : 1661-1665.

Jackson, C.R. 1965. Peanut pod mycoflora and kernel infection. Plant Soil 23 : 203212.

Jackson, C.R. 1967a. Effects of preplanting soil treatments on peanut losses and reduction of pod mycoflora in Georgia. Plant Dis. Rep. $51: 461-464$.

Jackson, C.R. 1967b. Evaluation of Terraclor Super $X$ for control of soilborne pathogens of peanuts in Georgia. Univ. Georgia Agric. Exp. Sta. Res. Rep. 4. 4 pp.

Jackson, C.R., and D.K. Bell. 1969. Diseases of peanut (groundnut) caused by fungi. Univ. Georgia Exp. Sta. Res. Bull. 56. $137 \mathrm{pp}$.

Johnson, W.C., J.P. Beasley Jr., S.S. Thompson, H. Womack, C.W. Swann, and L.E. Samples. 1987. Georgia peanut production guide. Univ. Georgia Agric. Coop. Ext. Ser. Bull. SB 23. 54 pp. 
Oniki, M., K. Kobayashi, T. Araki, and A. Ogosh. 1986. A new disease of turf-grass caused by binucleate Rhizoctonia AG-Q. Ann. Phytopathol. Soc. Jap. $52: 850-853$.

Papavizas, G.C. 1985. Trichoderma and Gliocladium: Biology, ecology, and potential for biocontrol. Annu. Rev. Phytopathol. $23: 23-54$

SAS Institute Inc. 1985. SAS user's guide: statistics, Version 5 ed. SAS Institute Inc. Cary, North Carolina. 956 pp.

Sumner, D.R., and D.K. Bell. 1982. Root diseases of corn induced by Rhizoctonia solani and Rhizoctonia zeae. Phytopathology $72: 86-91$.
Sumner, D.R., D.A. Smittle, E.D. Threadgill, A.W. Johnson, and R.B. Chalfant. 1986. Interactions of tillage and soil fertility with root diseases in snap bean and lima bean in irrigated multiple-cropping systems. Plant Dis. 70 : 730-735.

Turhan, G., and F. Grossmann. 1988. Antagonistic activity of Neocosmospora vasinfecta var. africana Cannon \& Hawksworth against soilborne fungi. J. Phytopathol. $123: 199-206$.

USDA. 1960. Index of plant diseases in the United States. United States Department of Agriculture Handbook. No. 165. Washington, DC. $531 \mathrm{pp}$. 